\title{
Impacts of Lesotho Highlands Water Project on Sustainable Livelihoods
}

\author{
Haretsebe Manwa (PhD) \\ Tourism Department,North West University \\ Private Bag X2046, Mmabatho, South Africa, 2735 \\ Email:23815310@nwu.ac.za or hamanwa@yahoo.com.au
}

\section{Doi:10.5901/mjss.2014.v5n15p640}

\begin{abstract}
The sustainable livelihood framework was used to understand and interpret communities' perceptions of the Lesotho Highlands Water Project's impacts on livelihoods in the highlands of Lesotho. In-depth interviews were held with representatives of households in three villages who were part of Phase $1 \mathrm{~A}$ of the Lesotho Highland Project. The results suggest that the Lesotho Highland Water Project has changed the livelihoods of the mountain people living nearby. The water project should embark on image building by involving people from the affected communities in setting up new priorities and a new vision concerning how the project can aid in sustaining the livelihoods of affected villages. Most importantly, the project should educate the concerned villages regarding its prime objectives and how communities can benefit from them.
\end{abstract}

Keywords: Sustainable development, Lesotho Highland Water Project, Livelihoods, Sociocultural, economic, environmental impacts, Tourism

\section{Introduction and Background}

Lesotho is one of the 15 members of the Southern African Development Community (SADC). It is a landlocked country completely surrounded by another country, South Africa, making it dependent on South Africa. Lesotho is classified as one of the least developed countries, with $50.1 \%$ of the population living below the poverty datum line. (United Nations Development Programme, 2008) Interestingly, poverty is acute mainly in the mountains where the Lesotho Highlands Water Project (LHWP) is based (Azubuike, 2006). It has a GDP of US\$1.60 billion (World Bank (2008). and is characterised by a high unemployment rate, estimated at 40\% (Kingdom of Lesotho, 2003-2004). Before the abolition of apartheid in South Africa, Lesotho's economy was sustained mainly by remittances from miners who worked in the Republic of South Africa (World Bank, 2000). Democratisation in South Africa has resulted in the retrenchment of Basotho miners, further exacerbating the very high unemployment rate. It has been noted that the restructuring of the South African mining industry led to the reduction in the number of Basotho mine migrant workers, estimated to be more than 125, 000 before 1994. The number of Basotho migrants, who were estimated to be about $50 \%$ of the total male labour force that was employed in South African gold mines, was reduced to 69, 000 in 1999 (World Bank, 2000)

Lesotho's main economic pillars are remittance from the Southern African Customs Union (SACU), which is comprised of Botswana, Lesotho, Namibia, South Africa and Swaziland. It is estimated that about US\$4 billion is generated from SACU, representing over $60 \%$ of the GDP. Other sources of revenue are through the African Growth and Opportunity Act (AGOA). AGOA is an agreement by the United States government to offer favourable export conditions for African textile exports. Lesotho has benefitted from AGOA through sale of textiles. Sale of textile generates $10 \%$ of Lesotho GDP, whilst the sale of water generates 5\%. LHWP, signed between the Kingdom of Lesotho and the Republic of South African in 1986, supplies water to the Gauteng province of South Africa. Lesotho's abundance of water has been referred to as its "white gold (Braun, 2011).

It is estimated that the sale of water to South Africa contributes $14 \%$ of the government's revenue, $25 \%$ of Lesotho's total annual export revenue, and 5\% of its GDP (Matli, 2005). Mochebelele further noted that during the construction of the first phase of the project, 3,000 jobs were created, yielding R275 million in wages (Mochebelele, 2000). The original objectives of the LHWP included the development of tourism, fisheries and other projects for social and economic development. The project is now in Phase 2, which is construction of another dam that will link to the first dams (Lesotho Highland Water Authority). The aim of this study was to establish community perceptions of the LHWP's impacts on livelihood. 


\section{Literature on Sustainable Livelihoods}

In September 2000, the world leaders adopted the United Nations Millennium Declaration the essence of which is to reduce extreme poverty by 2015 . These are popularly known as the Millennium Development Goals (http://www.un.org/milleniumgoals/bkgd.ahtml). Sustainable development has come on the forefront of various efforts to reduce poverty. Whilst policy makers and researchers have experimented with various strategies to reduce poverty, one of the most used frameworks is the sustainable livelihoods approach. The proponents of this approach argue that its strengths are its ability to successfully alleviate poverty, induce rural development and manage the environment sustainably (Ellis, 2000; Chambers and Conway, 1992). Chambers and Conway (1992: 7) defined sustainable livelihood as

"A livelihood comprises the capabilities, assets (including both material and social resources) and activities required for a means of living. A livelihood is sustainable when it can cope with and recover from stress and shocks maintain or enhance its capabilities and assets, while not undermining the natural resource base".

The sustainable livelihoods framework is considered a suitable tool for the analysis of livelihoods because it links the broader socio-economic components of household assets, livelihood activities, outcomes of livelihood activities, and factors mediating access to livelihood activities (Scoones, 1998; Farington et al., 2004). The sustainable livelihood framework shows how in different contexts and through different strategies, people support themselves through access to a range of resources or assets (natural, economic, human and social capitals (Chambers and Conway, 1992; Ashley and Hussein, 2006).

The sustainable livelihood framework adopted for this paper is the on developed by Scoones (1998). Scoones model has five elements: the contexts, conditions, trends (Exogenous factors at macro-level that influence communities including government policies). The second element of the model is the livelihood resources (natural capital, e.g. flora and fauna, economic/financial capital, human capital (skills, capacity, etc). The third element of the model is the institutional/organisational influences on access to livelihood resources. the fourth element of the model is referred to as the livelihood strategies. The last element in the model is the focus on sustainable livelihood outcomes. Scoones further emphasised that sustainability is a function of how assets and capabilities are utilised, maintained and enhanced so as to preserve livelihoods.

Scoones' framework has received a fair amount of criticisms. it is argued that the framework is not critical about contradicting terms such as vulnerability and sustainability, transformation (Arc (2003: 206). Another criticism of the framework is the problem of defining what assets entails, for example whether political power should be counted as part of the assets? (Smith, 2004). Furthermore, as Davis et al. (2008) note, the framework serves the agendas of external interests such as the donor community and not those of the poorest sectors of local communities. Other criticisms of the model include "fussy connection between capitals, resources and social actors" (Arc, 2003:206).

Despite these criticisms, the framework has received wide recognition and application. The model acknowledges that people's livelihoods are based on other activities besides formal jobs (Tao \& Wall, 2009:91). Tao and Wall further state that the framework highlights the adaptive strategies, participation and empowerment. Other proponents of the model see it as a useful framework for monitoring project development at all stages of the project (Farington et al., 1999). The model is relevant to the present study in that the study explores livelihood strategies in the light of the LHWP. It explores how people managed to cope with the changes in their livelihoods brought about by the project.

The study was guided by the following objectives:

1. To establish communities' perceptions of the impacts of the Lesotho Highland Water Project on their livelihoods

2. Whether tourism can complement other community livelihoods strategies

\section{Methodology}

This was a qualitative study aimed at seeking perceptions of the local communities on how the Lesotho Highlands Water Project (LHWP) has affected their livelihoods. This study utilised two data sources- desk research and in-depth interviews. The desk research involved a review of relevant literature on sustainable livelihoods and the Lesotho Highlands Water. An empirical study followed. The study therefore was a triangulation of methods whereby desk research and primary data were utilised. Primary data was collected through in-depth interviews with households of three villages around the Katse dam (Halejone, Hatheko and Hasoai). 


\subsection{Population}

This was a qualitative study. therefore there was no sampling method adopted instead we approached the important stakeholders in each village (the chief, members of the Village Development committees, cooperative members and a few households to seek their views on the impacts of the LHWP on their livelihoods. Subsequently 40 people were interviewed in each village which came up to 120 people in all.

\subsection{Procedures}

A letter was written to the chief of each village, informing him or her about the study and seeking permission to interview villagers. Upon our arrival, we paid our homage to the chief and introduced the research team.

Two research assistants were employed for the research. The requirement for appointment was fluency in both Sesotho (local language) and English. This was important as the interview guidelines had English and a Sesotho version. In each village, we did a rough count of the number of households and divided the village into three sections. Each researcher was instructed to interview any household that was available for an interview. At each homestead, we asked who the most senior person was and whether he or she was willing to sit with us for a few minutes to answer our questions. The household interviews were conducted in either English or in Sesotho (local language), depending on the literacy of the interviewee. The interview guidelines included four major sections including demographic data, perceptions on LHWP impacts on livelihoods.

\subsection{Response rate}

LHWP estimates that there are 372 households living in the Phase A of the project area. A total of 120 households were interviewed.

\subsection{Study area}

We chose three villages: Halejone, the first village signalling the beginning of the Katse dam, located 50 kilometres from the dam wall; Hatheko, the village opposite the Katse dam wall, roughly around 10 kilometres from the LHDA's head office; and Hasoai, located downstream from the Lesotho Highland Water Project Phase 1A, about 30 kilometres from the Katse dam. It is the village located at the confluence of Matsoku and Malibamatso rivers, which will feed into Phase 2 of the project. According to LHWP records, the project is engaged in community-based projects involving surrounding villagers. For example, the Bokong Nature Reserve (1953 ha) was created to, among other things, conserve endangered species due to the construction of the project. It houses some of Lesotho's endangered species, such as the bearded vulture, the Vaal rhebuck, and the endemic ice rat. The reserve is also meant to create business opportunities for local communities. Some activities include local guides for mountaineers and pony trekkers, and selling local crafts at the reserve's visitor's centre in Hatheko.

\section{Findings of the Study}

\subsection{Demographics}

Ages of respondents are presented in Table 1. Of the 120 individuals, most were over the age of 50 years (41\%). The least represented were those younger than 30 years. It is not surprising that younger people were not represented, as the interviewees noted that there are few jobs and little farming occurring in the mountain region. Young people have migrated to the lowland region in search of paid employment. Another important aspect of the study is that the older people in the villages experienced life before and after the project. The older residents have a good grasp of developments in the region, including impacts of the Lesotho Highland Water Project on people's livelihoods. The views reflected in this research can therefore be trusted to represent the general views held by those affected by the construction of the water project.

In terms of gender, $67 \%$ of the respondents were female and $33 \%$ were male. This was not surprising, as in most African countries, most men go to look for work in the cities while women stay in the villages, looking after the homesteads and farming. 
Table 1: Ages of Respondents

\begin{tabular}{|c|c|c|}
\hline Age Range & Number & $\%$ \\
\hline Below 30 years & 12 & 10 \\
\hline $30-39$ & 28 & 23 \\
\hline $40-49$ & 31 & 26 \\
\hline $50+$ years & 49 & 41 \\
\hline Total & 120 & $100 \%$ \\
\hline
\end{tabular}

The educational attainment of the respondents is shown in Table 2. The results show that the majority of the interviewees had primary education (53\%), while a third of the respondents (33\%) had no formal education.

Table 2: Educational levels of respondents

\begin{tabular}{|c|c|c|}
\hline Educational attainment & Number & $\%$ \\
\hline No formal education & 40 & 33 \\
\hline Primary education & 64 & 5 \\
\hline Secondary education & 14 & 1 \\
\hline Tertiary education & 2 & 2 \\
\hline Total & 120 & 100 \\
\hline
\end{tabular}

In terms of livelihood, $98 \%(N=118)$ of the interviewees stated that their livelihoods were dependent on land resources, through ploughing and cattle and sheep farming. Only $2 \%(\mathrm{~N}=2)$ were dependent on the sale of crafts or worked in Maseru. We could not establish the average family earnings per annum since the interviewees could not translate agricultural produce into monetary earnings.

\subsection{Perceptions of LHWP Impacts}

According to Table 3, LHWP has had very limited positive impacts on the livelihoods of the villagers. Communities have experienced more losses than gains to their livelihoods, including the death of villagers and animals through drowning, loss of traditional assets, lack of stakeholder analysis, changes in social relations, triggering of earth tremors, and the cracking and collapsing of houses.

The respondents described the fatalities from drowning. People and animals were losing their lives from drowning. Many of the villagers alleged that there were no prior warnings during the opening up of tunnels to reduce excess water during high-level water inflows in the dam. This results in flooding the river downstream. Bridges also collapsed, resulting in loss of life. Perhaps even more surprising though that despite these fatalities, Hatheko, which was the closest village to Katse Dam wall was not fenced off from the dam to avoid drowning of animals and people.

Loss of important resources, such as land, was highlighted by all the respondents. Villagers complained that the compensation is not enough. The land they have lost is an inheritable resource passed on to others beyond the current owner to future generations. LHWP compensation, on the other hand, has a time frame of 50 years. Families feel they have experienced property disenfranchisement, in that they will not benefit from the compensation once the claimant is dead or after 50 years. Added to the disruption of livelihood, then, the compensation usually comes late or never at all, and sometimes the wrong person gets compensated. We were informed of cases where the brother of the diseased head of the household was compensated instead of the widow. In addition, whereas land can now be developed with new technology to provide a higher yield, the compensation does not take into account the intrinsic and extrinsic value of land.

The study clearly reflects the dependency of the mountain villages on the rivers. These are mountainous places with very little arable space. There is crowding and competition for land resources, space for grazing, ploughing fields, residential areas, food staffs, firewood, and so on. Hence, the bitterness for the little land that has been taken away through the construction of the roads and dams. Many more families are crowded in small spaces. It is clear that there has not been adequate compensation for the loss of livelihood.

This study showed, however, that there are some elements of top-down decision making by LHWP, whereby the project officials believe that they can dictate how the compensation money should be used. We were told of confrontations between LHWP community development officer (the name disclosed to us) and the communities. They threatened to beat her up should she come back to the village. Apparently, she told the villagers that the project would 
stop paying compensation unless they agreed to use the money for village developments projects-to be decided by LHWP. The villagers instead preferred to "keep their money in the bank and draw on the interest earned rather than squander their money and leave their families nothing."

Respondents unanimously agreed that support for cooperatives is a positive impact of the LHWP. This was mentioned by over $80 \%$ of respondents in the three villages. When villagers were asked why they considered this a positive development, we were informed that cooperatives are able to secure farming implements such as seeds for maize and bean cultivation and other farming implements, which have improved crop yield.

There were strong views regarding climate changes that were attributed to LHWP. In the three villages, natural climatic changes that could be normal developments, such as extreme temperatures, frequent droughts, and strong winds, were all blamed on the project. Whilst the dam water is visibly abundant, it is, however, unavailable for irrigation and farming.

There have been improvements in infrastructure development, whereby roads have made the areas accessible. More importantly, villagers are now able to access major commercial centres for social services such as schools, health centres and shopping centres. However, the project has also been a barrier to social networks. It is difficult to access friends or family who reside across the river.

The respondents did not see tourism as a positive impact of the LHWP. This is contrary to one of the key objectives of the project, which was to develop community-based tourism and development of fisheries (LHWP, 1987). Indeed, our observations were that the tourism development was restricted to Halejone, where there were accommodation facilities for tourists.

Development of fisheries was only mentioned by respondents from Halejone, who have benefitted from the community project from the breeding of trout, which created employment for members of the community. The respondents from Halejone also mentioned the fact that the money from the sale of trout is used for community development projects. This was not the case in the other two villages (Hatheko and Hasoai).

Provision of clean water was not perceived by communities as a positive impact on their livelihoods. There were disputes regarding unfulfilled promises to provide clean water from boreholes. Communities felt let down on the promise of clean water. The boreholes have either broken down or are not operating efficiently. For example, in Hasoai, the borehole uses solar panels for power generation. Villagers told us that the flow of water was very slow. It appears to be a matter of lack of maintenance, where the solar pumps were not serviced to ensure that they operate efficiently and new solar batteries with a higher capacity have not been used.

Communication between the project and the community is very poor. For example, the project is still accused of not providing people with accurate information concerning compensation. Flooding of the river downstream is not communicated to the villages and results in drowning and loss of life.

Table 3: Perceptions of LHWP's Impacts on Livelihoods Categorised by Village

\begin{tabular}{|c|c|c|c|}
\hline Village & Economic Impacts & Sociocultural Impacts & Environmental Impacts \\
\hline \begin{tabular}{|l|} 
Hasoai \\
Positive \\
\end{tabular} & - Support for cooperatives (90\%) & & - Tree planting (10\%) \\
\hline Negative & $\begin{array}{l}\text { - Loss of access to natural } \\
\text { resources (river sand, thatching } \\
\text { grass, fish, fruits, flora, medicinal } \\
\text { plants; } 90 \%) \\
\text { - Loss of earnings ( } 45 \%) \\
\text { - Loss of resources }(70 \%) \\
\text { - Unfair compensation }(65 \%)\end{array}$ & $\begin{array}{l}\text { - Cut off from neighbouring villages } \\
\text { (Tlokoeng and Ha- Ramoalosi; 40\%) } \\
\text { - Social ills (e.g., corruption; (20\%) } \\
\text { - Community development projects (30\%) } \\
\text { - Loss of inheritance/identity (89\%) } \\
\text { - Break down of social structures (65\%) } \\
\text { - Top-down communication (56\%) }\end{array}$ & $\begin{array}{l}\text { - Destruction of flora and fauna (55\%) } \\
\text { - Loss of life through drowning (people, } \\
\text { - } \text { animals and plants; } 100 \%) \\
\text { - Destruction of trees }(20 \%) \\
\text { - Drying of the rivers (80\%) } \\
\text { - Soil erosion (60\%) } \\
\text { - Vulnerability to droughts; inability to use } \\
\text { - LHWP water for irrigation (60\%) } \\
\text { - Infrastructure development }(90 \%) \\
\text { - Building of toilets (20\%) } \\
\text { - Dirty water for the animals (43\%) }\end{array}$ \\
\hline $\begin{array}{l}\text { Halejone } \\
\text { Positive }\end{array}$ & $\begin{array}{l}\text { - Support for cooperatives (89\%) } \\
\text { - Creation of jobs at the early } \\
\text { stages of the project (5\%) } \\
\text { - Electricity and businesses (50\%) }\end{array}$ & & \\
\hline
\end{tabular}




\begin{tabular}{|c|c|c|c|}
\hline Negative & $\begin{array}{l}\text { - Transport too expensive }(30 \%) \\
\text { - Jobs at the trout farm and money } \\
\text { coming to the community }(50 \%)\end{array}$ & $\begin{array}{l}\text { - Odd priorities: throwing a Christmas party } \\
\text { for villagers instead of delivering on } \\
\text { promises }(20 \%) \\
\text { - Loss of arable land and pastures }(70 \%) \\
\text { - Loss of cultural values (inheritance; } \\
80 \% \%) \\
\text { - Unfair compensation (80\%) } \\
\text { - Boreholes broken down and not repaired } \\
(80 \%)\end{array}$ & $\begin{array}{l}\text { - Loss of river resources (e.g., firewood, } \\
\text { river sand, fetching grass, fishing, local } \\
\text { medicines) } \\
\text { - Cut off from other villages (60\%) } \\
\text { - Extreme temperatures, cold wind from } \\
\text { the dam ( } 80 \%) \\
\text { - Vulnerable to droughts and extreme } \\
\text { temperatures (50\%) } \\
\text { - Lack of maintenance of water pipes } \\
\text { (always broken down; } 56 \%) \\
\text { - Loss of life and animals through } \\
\text { drowning bridge collapsing (80\%) }\end{array}$ \\
\hline \begin{tabular}{|l|} 
Hatheko \\
Positive
\end{tabular} & $\begin{array}{l}\text { - Support for formation of } \\
\text { cooperatives }(80 \%)\end{array}$ & & $\begin{array}{l}\text { - } \text { Tree planting (30\%) } \\
\text { - Infrastructure development (e.g., } \\
\text { community halls; } 60 \%) \\
\text { - Construction of toilets (32\%) }\end{array}$ \\
\hline Negative & $\begin{array}{l}\text { - Loss of livelihoods }(98 \%) \\
\text { - Economic dependency/poverty } \\
\text { (70\%) } \\
\text { - Loss of pastures and fields (90\%) } \\
\text { - Cash economy }(50 \%)\end{array}$ & $\begin{array}{l}\text { - Restricted movement (80\%) } \\
\text { - Education about HIVIAIDS (65\%) } \\
\text { - High teenage pregnancies (52\%) } \\
\text { - Broken promises, e.g. relocation, } \\
\text { payment for cracked or collapsed houses } \\
\text { - Implementation problems e.g. change of } \\
\text { beneficiary }\end{array}$ & $\begin{array}{l}\text { - Loss of access to river resources (e.g., } \\
\text { fish, plants, fruits, medicinal plant, river } \\
\text { sand; } 98 \% \text { ) } \\
\text { - } \text { Loss of trees (68\%) } \\
\text { - Vulnerable to drought: water not used } \\
\text { to irrigate their fields (90\%) } \\
\text { - Too close to the dam and no fence } \\
\text { drowning of children, animals and } \\
\text { suicides (100\%) } \\
\text { - Tremors, houses collapsed/cracked } \\
\text { (80\%) } \\
\text { - Strong winds blowing away their } \\
\text { houses (90\%) } \\
\text { - Cut-off from neighbouring villages (e.g., } \\
\text { Ha-Khokhoba; 69\%) }\end{array}$ \\
\hline
\end{tabular}

\section{Implications for the Lesotho Government/LHWP}

The issue of compensation remains a thorny issue. Perhaps this needs to be reviewed in order to come up with a more acceptable model of compensation. Community involvement and consultation might generate other alternatives (Moscardo, 2008).

The development of alternative livelihoods is perhaps more appropriate than focusing on the loss of land for farming and grazing (Moscardo, 2005. The project should have accelerated development of fisheries and tourism as a means of income generation to alleviate land loss (Braun \& McLees, 2011; Blake et al., 2008; Davies et al., 20080. Halejone village is an example where fisheries are being developed for the benefit of the community. LHWP could speed up the development of fisheries in other villages. More importantly, tourism is stipulated as one of the main objectives of the LHWP. The development of tourism could be speeded up as well (Simpson, 2007). Communities are already endowed with unique tourism resources, such as the landscape, the culture, and the LHWP, which is one of the largest water projects in Africa.

There is lack of transparency in consultation of affected communities on the decisions being undertaken by the project. For example, downstream villages are not given adequate warning on the possibility of flooding as a result of opening up of tunnels to release pressure. This can easily be communicated to communities to avoid the drowning of people and animals. This is already done for other weather calamities, such as heavy snowfall, where the Lesotho government takes all precautionary measures to warn communities through radio and other means to avoid travelling to the affected areas so there is no loss of life.

The project has not redressed the miscommunication of the objectives of the project, including the misconceptions that water from the project would be made available for irrigation of fields and crops. Negative environmental impacts, like earth tremors and strong winds, resulting from large volumes of water bodies have not been explained to the communities. 


\section{Conclusion}

The aim of the study was to establish people's perceptions of the economic, sociocultural and environmental impacts of the LHWP on livelihood. In particular, the study aimed to assess whether tourism could become a meaningful livelihood option. The study findings have confirmed that, in the majority of cases, there still prevail negative perceptions of the project. The majority believe that the project has deprived them of their sustainable livelihoods. In conclusion, I would like to agree with Friedman (1992) that "if social and economic development mean anything at all, it must mean a clear improvement in the conditions of life and livelihood of ordinary people."

\section{References}

Arce, A. (2003). Value contestations in development interventions: Community development and sustainable livelihoods approaches. Community Development Journal, 38(3),199-212.

Ashley, C., \&. Hayson, G. (2006). From philanthropy to a different way of doing business: Strategies and challenges in integrating propoor approaches into tourism business. Development Southern Africa, 23 (2), 265-280.

Azubuike, E. (2006). Progress on poverty alleviation in Lesotho (1994-2003): A capability approach. Dissertation submitted in partial fulfilment for the Masters in Development Studies in the Faculty of Economic and Management Sciences (Centre for Development Support), University of Free State.

Blake, A., Arbache, J.S., Sinclair, M.T., \& Teles, V. (2008). Tourism and poverty relief. Annals of Tourism Research, 35(1), 107-126.

Braun, Y.A. (2011). The reproduction of inequality: race, class, gender, and the social organization of work at sites of large-scale development projects. Social Problems, 58 (2), 281-303.

Braun, Y.A. \& McLees, L.A. (2012). Space, ownership and inequality: Economic development and tourism in the highlands of Lesotho. Cambridge Journal of Regions, Economy and Society, 5 (3), 435-449.

Chambers, R., \& Conway, G.R. (1992). Sustainable rural livelihoods: Practical concepts for the 21 $1^{\text {st }}$ century". IDS discussion paper 296, Brighton, UK: Institute of Development Studies, University of Sussex.

Davies, J. A, D, White, J. B, Wright, A. C, Maru, Y.A., \& LaFlamme, M. (2008). Applying the sustainable livelihoods approach in Australian desert Aboriginal development. The Rangeland Journal, 30, 55-65.

Ellis, F. (2000). Rural livelihoods and diversity in developing countries. Oxford: Oxford University Press

Farington, J., Slater, R., \& Holmes, R. (2004). Social protection and pro-poor agricultural growth: What scope for synergies? Natural Resource Perspective, Number 91, ODI.

Farington, J., Carney, D., Ashley, C., \& Turton, C. (1999). Sustainable livelihoods in practice: Early application of concepts in rural areas. ODI Natural Resources Perspectives 42 (June).

Friedman, J. (1992). Empowerment: The Politics of an Alternative Development (Oxford: Blackwell, 1992

Kingdom of Lesotho's Vision 2020 Framework. http://www.lesotho.gov.Is/home/default.php.

Kingdom of Lesotho. 2009. http://www.lesotho.gov.Is/about/tourism.php

Kingdom of Lesotho. 2004/2005- 2006/2007. Poverty Reduction Strategy. http://www.lesotho.gov.Is/home/default.php

Matli, M.B. (2005). The social impacts of a large development project: Lesotho Highlands water project. Msc dissertation, University of the Free State, South Africa.

Mochebelele, R.T. (2000). Lesotho highland water Project- concerns and benefits of dams including the environmental and social impacts and the associated mitigation measures for sustainability. World commission on dams. http://www.org/kbase Isubmissions/sublist.php?rec=ins098

Moscardo, G. (2008). Community capacity building: an emerging challenge for tourism development in Gianna Moscardo (eds) (Chapter 1: 1-15). Building Community Capacity for Tourism Development. Oxfordshire: CABI publishers.

Moscardo, G. (2005). Peripheral Tourism Development: Challenges, issues and success factors. Tourism Recreation Research, 30 (1), $27-43$.

Mwangi, O. (2007). Human security in Lesotho: a case study of Lesotho Highlands Water Project. Journal of Southern African Studies, $33(1), 3-17$

Saarinen, J. (2006). Traditions of sustainability in tourism. Annals of Tourism Research, 33(4), 1121-1140.

Scoones, I. (1998). Sustainable rural livelihoods: a framework for analysis. Institute of Development Studies Working Paper 72.

Simpson, M.C. (2007). An integrated approach to assess the impacts of tourism on community development and sustainable livelihoods. Community Development Journal, 44 (2), 186-208.

Smith, L.E.D. (2004). Assessment of the contribution of irrigation to poverty reduction and sustainable livelihoods, International Journal of Water Resources Development, 20 (2), 243-257.

Tao, T.C.H., \& Wall, G. (2009). Tourism as a sustainable livelihood strategy. Tourism Management, 30, 90-98.

United Nations Development Programme (2008). Human Development Report: Statistical Update. Accessed 30 January 2010 from http://hdr.undp.org/en/statistics/.

World Bank (2008). Kingdom of Lesotho Interim Poverty Reduction Strategy Paper. Report Number 21834.

World Bank (2007). Implementation, completion and results Report: Lesotho Highland Water Project Phase 1B. Report Number ICR168. 
